\title{
Soil fauna and its relation with environmental variables in soil management systems ${ }^{1}$
}

\author{
Fauna edáfica e sua relação com variáveis ambientais em sistemas de manejo do solo
}

\author{
Dilmar Baretta ${ }^{2 *}$, Marie Luise Carolina Bartz ${ }^{3}$, Ivandro Fachini², Rafael Anselmi², Talyta Zortéa ${ }^{2}$ e Carolina \\ Riviera Duarte Maluche Baretta ${ }^{4}$
}

\begin{abstract}
The present study aims to generate knowledge about the soil fauna, its relation to other explanatory environmental variables, and, besides it, to select edaphic indicators that more contribute to separate the land use systems (LUS). Five different LUS were chosen: conventional tillage with crop rotation (CTCR); no-tillage with crop rotation (NTCR); conventional tillage with crop succession (CTCS); no-tillage with crop succession (NTCS) and minimum tillage with crop succession (MTCS). The samples were made in the counties Chapecó, Xanxerê and Ouro Verde located in the state of Santa Catarina, Brazil, and were considered the true replicates of the LUS. In each site, nine points were sampled in a sampling grid of $3 \times 3$. At the same points, soil was sampled for the physical, chemical and biological attributes (environmental variables). Pitfall traps were used to evaluate the soil fauna. Data were analyzed using principal component analysis (PCA) and canonical discriminant analysis (CDA). The soil fauna presented potential to be used as indictors of soil quality, since some groups proved to be sensible to changes of the environmental variables and to soil management and tillage. The soil management using crop rotation (NTCR and CTCR) presented higher diversity, compared to the systems using crop succession (NTCS, MTCS and NTCS), evidencing the importance of the soil tillage, independent of the season (summer or winter). The variable that better contributed to explain these changes were the chemical variables (potassium, $\mathrm{pH}$, calcium, organic matter, available phosphorus, potential acidity), and biological variables (Shannon diversity index, Collembola, Pielou equitability index and microbial biomass carbon), respectively.
\end{abstract}

Key words: Sustainability. Soil quality indicators. No-tillage. Conventional tillage.

RESUMO - O presente estudo objetivou gerar conhecimento sobre a fauna edáfica e sua relação com outras variáveis ambientais explicativas, além de selecionar os indicadores edáficos que mais contribuem para separar os sistemas de uso do solo (SUS). Foram escolhidas cinco SUS, sendo: plantio convencional com rotação de culturas (CTCR); plantio direto com rotação de culturas (NTCR), plantio convencional com sucessão de culturas (CTCS), plantio direto com sucesso de culturas (NTCS) e cultivo mínimo com sucessão de culturas (MTCS). As amostragens foram realizadas nos municípios catarinenses de Chapecó, Xanxerê e Ouro Verde e estes foram considerados como repetições verdadeiras dos SUS. Em cada área foram amostrados nove pontos, em uma grade amostral 3x3. No mesmo ponto, foram coletadas amostras para avaliação de alguns atributos físicos, químicos e biológicos do solo (variáveis ambientais). A fauna do solo foi avaliada utilizando armadilhas do tipo "Pitfall traps". Os dados foram analisados por meio de análises de componentes principais (PCA) e canônica discriminante (ACD). A fauna edáfica apresentou potencial para ser usada na avaliação da qualidade do solo, pois alguns grupos se mostraram sensíveis às alterações nas variáveis ambientais, ao preparo e manejo do solo. Os SUS com rotação de culturas (NTCR e CTCR) apresentaram a maior diversidade edáfica, em comparação aos com sucessão de culturas (CTCS, NTCS e MTCS), evidenciando a importância do cultivo do solo, independente da época de amostragem (inverno e verão). As variáveis que contribuíram mais para explicar essas modificações nos SUS foram os atributos químicos: potássio, pH, cálcio, matéria orgânica, fósforo disponível, acidez potencial e os biológicos: índice de diversidade de Shannon, Collembola, índice de equitabilidade de Pielou e carbono da biomassa microbiana do solo, respectivamente.

Palavras-chave: Sustentabilidade. Indicadores de qualidade do solo. Plantio direto. Plantio convencional.

\footnotetext{
*Autor para correspondência

Recebido para publicação em 27/01/2014; aprovado em 13/06/2014

Pesquisa realizada com suporte financeiro da Fundação Agrisus pelo projeto PA 741/10

${ }^{2}$ Centro de Educação Superior do Oeste, Universidade do Estado de Santa Catarina, Rua Beloni Trombeta Zanin 680E, Santo Antônio, Chapecó-SC, Brasil, 89.815-630, dilmar.baretta@udesc.br, ivandro.iaf@hotmail.com,rafinha_anselmi@hotmail.com, talizortea@hotmail.com ${ }^{3}$ Programa de Pós-Graduação em Gestão Ambiental, Universidade Positivo, Curitiba-PR, Brasil, bartzmarie@up.edu.br

${ }^{4}$ Centro de Educação Superior do Oeste, Universidade do Estado de Santa Catarina, Campus Chapecó e do Curso de Agronomia, Universidade Comunitária da Região de Chapecó-UNOCHAPECÓ, Brasil, carolmaluche@bol.com.br
} 


\section{INTRODUCTION}

There are many inter-relations between physical, chemical and biological attributes in the soil which control the processes and related aspects to its variation in time and space (BARETTA et al., 2006; BROOKES, 1995; LAVELLE et al., 2006; PEREIRA et al., 2013). The evaluation of these environmental variables in different agricultural systems consists in an important tool to define the better management to be adopted, contributing to a higher quality and sustainability of the system.

The adoption of conservation management systems has emerged as a viable alternative to ensure the sustainability of agricultural land use (BARTZ et al., 2013; HUNGRIA et al., 2009; SILVA et al., 2000). In this context, the no-tillage (NT), different of the other types of soil management systems, as the minimum tillage (MT) and conventional tillage (CT), is the best option for the maintenance and improvement of soil attributes.

The NT is a system that has been widely used in the western region of the state of Santa Catarina which principles are the minimal soil disturbance, permanent soil cover, less susceptibility to soil erosion, and crop rotation, therefore providing the basis to accumulation of organic matter, important for physical, chemical and biological balance of the soil (BARETTA et al., 2003; BARTZ et al., 2013; FEBRAPDP, 2013).

The different types of tillage and cover can influence the quality of the attributes of soil, because there are differences such as the relation $\mathrm{C}: \mathrm{N}$, which influences the speed of the straw degradation, and can also change the diversity of the soil fauna (BARETTA et al., 2003; BARTZ et al., 2014). The sort of soil tillage associated to crop rotation can modify the soil physical, chemical e biological attributes, promoting modifications on the populations of soil organism that lives in soil, through direct and indirect effects on factors related to soil and plants (ALVES et al., 2006; DUPONT et al., 2010).

The influence of soil management on the biological component usually presents a quicker response than the other edaphic attributes, serving as sensitive indicators of ecological changes in agroecosystems. Thereby, the knowledge of fauna and their ecological relations are important for the evaluation of soil quality and to the understanding of the dynamics of production systems (LAVELLE et al., 2006; LIMA et al., 2013; PAOLETTI; BRESSAN, 1996; SILVA et al., 2006; SILVA et al., 2013).

In Brazil, the research related to different soil management systems, focused in the study of physical and chemical parameters solely and there are a small number of papers analyzing chemical, physical and biological soil properties together (PEREIRA et al., 2013). In this way, the present study comes to contribute with information on soil fauna and its relationship with environmental variables, and also aims to select environmental variables that contribute to separate the land use systems in the western region of Santa Catarina.

\section{MATERIAL AND METHODS}

The study was carried out in the western region of Santa Catarina (SC) state, Brazil, in Chapecó and in the neighbor counties Xanxerê and Ouro Verde (Table 1). Climate in the region is temperate humid with warm summer $(\mathrm{Cfa})$ (Koeppen classification), with mean temperatures $18-22{ }^{\circ} \mathrm{C}$ and annual mean rainfall of $2000 \mathrm{~mm}$. The region show no marked dry season and rainfalls throughout the year. The soil in the five land use system (LUS) was classified as a Rhodic Hapludox (USDA, 1999).

For this study five land use system (LUS) were chosen representing the western region of Santa Catarina (Table 1), with similar soil conditions (soil type) and slope: conventional tillage with crop rotation (CTCR); no-tillage with crop rotation (NTCR); conventional tillage with crop succession (CTCS); no-tillage with crop succession (NTCS) and minimum tillage with crop succession (MTCS). The counties Chapecó, Xanxerê and Ouro Verde were considered true replicates of the LUS and in each site nine points distant $15 \mathrm{~m}$ from each other were sampled on a regular grid $(3 \times 3)$ leaving 10 meters from the plot boundaries, totalizing approximately half hectare in area (adaptation of BARTZ et al., 2014). Due to lack of knowledge about the variability of soil properties in the site, the extent of each sample plot was small, in order to avoid effects other than those provided by soil tillage and management (Table 2).

For the evaluation of soil fauna and microbiological variables, samplings were done in two seasons: summer (December 2009) and winter (July 2010). Samplings for the physical and chemical analysis were carried out in summer. All these samplings were carried out at the same evaluation points of soil fauna at a depth of $0-20 \mathrm{~cm}$. The results of the chemical attributes of each LUS (mean of the counties) are presented in Table 2.

The soil moisture was measured using a "Falker Hidrofarm" and the resistance to penetration of the soil was performed using the penetrometer type "Falker penetroLOG" to a depth of $20 \mathrm{~cm}$, doing readings every $10 \mathrm{~mm}$ for each site. The chlorophyll content of each plant at the time of collection was determined using a "Clorofilog Falker" and evaluating three points in one plant near the soil sampling points. 
Table 1 - Georeferenced points (Latitute, Longitute and Altitute) in land use system (LUS) and slope: conventional tillage with crop rotation (CTCR); no-tillage with crop rotation (NTCR); conventional tillage with crop succession (CTCS); no-tillage with crop succession (NTCS) and minimum tillage with crop succession (MTCS) in the counties Chapecó, Xanxerê and Ouro Verde, state of Santa Catarina, Brazil

\begin{tabular}{|c|c|c|c|c|}
\hline County & LUS & Latitute (S) & Longitute (W) & Altitute (m) \\
\hline \multirow{5}{*}{ Chapecó } & CTCR & $27^{\circ} 11^{\prime} 37^{\prime \prime}$ & $52^{\circ} 39^{\prime} 34^{\prime \prime}$ & 660 \\
\hline & NTCR & $27^{\circ} 11^{\prime} 36^{\prime \prime}$ & $52^{\circ} 39^{\prime} 33^{\prime \prime}$ & 661 \\
\hline & CTCS & $27^{\circ} 11^{\prime} 34^{\prime \prime}$ & $52^{\circ} 39^{\prime} 32^{\prime \prime}$ & 668 \\
\hline & NTCS & $27^{\circ} 11^{\prime} 33^{\prime \prime}$ & $52^{\circ} 39^{\prime} 31^{\prime \prime}$ & 670 \\
\hline & MTCS & $27^{\circ} 11^{\prime} 38^{\prime \prime}$ & $52^{\circ} 39^{\prime} 48^{\prime \prime}$ & 654 \\
\hline \multirow{5}{*}{ Xanxerê } & CTCR & $26^{\circ} 49^{\prime} 45^{\prime \prime}$ & $52^{\circ} 28^{\prime} 18^{\prime \prime}$ & 788 \\
\hline & NTCR & $26^{\circ} 49^{\prime} 42^{\prime \prime}$ & $52^{\circ} 28^{\prime} 19^{\prime \prime}$ & 783 \\
\hline & CTCS & $26^{\circ} 49^{\prime} 41^{\prime \prime}$ & $52^{\circ} 27^{\prime} 33^{\prime \prime}$ & 784 \\
\hline & NTCS & $26^{\circ} 49^{\prime} 43^{\prime \prime}$ & $52^{\circ} 28^{\prime} 17^{\prime \prime}$ & 786 \\
\hline & MTCS & $26^{\circ} 49^{\prime} 48^{\prime \prime}$ & $52^{\circ} 27^{\prime} 36^{\prime \prime}$ & 793 \\
\hline \multirow{5}{*}{ Ouro Verde } & CTCR & $26^{\circ} 43^{\prime} 08^{\prime \prime}$ & $52^{\circ} 18^{\prime} 06^{\prime \prime}$ & 750 \\
\hline & NTCR & $26^{\circ} 43^{\prime} 09^{\prime \prime}$ & $52^{\circ} 18^{\prime} 18^{\prime \prime}$ & 757 \\
\hline & CTCS & $26^{\circ} 43^{\prime} 07^{\prime \prime}$ & $52^{\circ} 18^{\prime} 09^{\prime \prime}$ & 768 \\
\hline & NTCS & $26^{\circ} 43^{\prime} 04^{\prime \prime}$ & $52^{\circ} 18^{\prime} 05^{\prime \prime}$ & 776 \\
\hline & MTCS & $26^{\circ} 43^{\prime} 06^{\prime \prime}$ & $52^{\circ} 18^{\prime} 07^{\prime \prime}$ & 759 \\
\hline
\end{tabular}

Table 2 - Summer and winter crops in the sampled land use systems (LUS) in the last six years in conventional tillage with crop rotation (CTCR); no-tillage with crop rotation (NTCR); conventional tillage with crop succession (CTCS); no-tillage with crop succession (NTCS) and minimum tillage with crop succession (MTCS)

\begin{tabular}{|c|c|c|c|}
\hline \multirow{2}{*}{ LUS } & \multicolumn{3}{|c|}{ CROPS } \\
\hline & & Summer & Winter \\
\hline CTCR & Corn $(Z e a$ & $\begin{array}{l}\text { mays), bean (Phaseolus vulgaris) and } \\
\text { soybean (Glycine max) }\end{array}$ & $\begin{array}{l}\text { Annual ryegrass (Lolium multiflorum), vetch (Vicia } \\
\text { sativa), black oats (Avena stringosa), rye (Secale } \\
\text { cereale), white lupine (Lupinus albus) }\end{array}$ \\
\hline NTCR & & Corn, bean and soybean & Annual ryegrass, vetch, black oast, and white lupine. \\
\hline CTCS & & Corn and soybean & Annual ryegrass, blackoats, vetch. \\
\hline NTCS & & Corn and soybean & Annual ryegrass, blackoats, vetch. \\
\hline MTCS & & Corn and soybean & Annual ryegrass, blackoats, vetch. \\
\hline
\end{tabular}

The soil chemical attributes analyzed were: $\mathrm{pH}$ in $\mathrm{CaCl}_{2}, \mathrm{P}$ (Mehlich-1), K (potassium), Ca (calcium), $\mathrm{Mg}$ (magnesium), $\mathrm{H}+\mathrm{Al}$ (potential acidity), $\mathrm{OM}$ (organic matter by Walkley-Black Method) and sum of bases, according to the methods described in Tedesco et al. (1995) (Table 3).

For the microbiological attributes, part of the soil of the chemical samples were taken, identified, placed in plastic bags and transported in coolers with ice to the laboratory. The samples were sieved to $2 \mathrm{~mm}$. The determination of the microbial biomass carbon (MBC) was performed with the fumigation-extraction method (VANCE et al., 1987). The basal respiration $\left(\mathrm{CO}_{2}-\mathrm{C}\right)$ was estimated using $50 \mathrm{~g}$ of soil (ALEF; NANNIPIERI, 1995), by quantifying the $\mathrm{CO}_{2}$ released of the microbial respiration process in a period ten days of incubation at $28{ }^{\circ} \mathrm{C}$.

Soil fauna sampling was performed using the "Pitfall traps" sampling method, by installing nine traps distributed in each LUS. The traps consisted in cylinders of $8 \mathrm{~cm}$ in diameter and $500 \mathrm{~mL}$ capacity, installed with the openings close to the soil surface, filled with $200 \mathrm{~mL} 0.5 \%$ (v/v) 
Table 3 - Soil chemical attributes of the land use systems (LUS), sampled at $0-20 \mathrm{~cm}$ depth, in the west region of Santa Catarina

\begin{tabular}{|c|c|c|c|c|c|c|c|c|}
\hline \multirow{2}{*}{ LUS } & \multirow{2}{*}{$\mathrm{pH} \mathrm{CaCl}{ }_{2}$} & $\mathrm{P}$ & $\mathrm{K}$ & $\mathrm{Ca}$ & $\mathrm{Mg}$ & $\mathrm{H}+\mathrm{Al}$ & \multirow{2}{*}{$\frac{\mathrm{MO}}{\mathrm{g} \mathrm{dm}^{-3}}$} & \multirow{2}{*}{$\frac{\mathrm{SB}}{\%}$} \\
\hline & & \multicolumn{2}{|c|}{$\mathrm{mg} \mathrm{dm}^{-3}$} & \multicolumn{3}{|c|}{$\mathrm{cmol}_{\mathrm{c}} \mathrm{dm}^{-3}$} & & \\
\hline CTCR & 5.4 & 13.8 & 272 & 7.3 & 3.7 & 4.4 & 40 & 72.7 \\
\hline NTCR & 5.8 & 21.6 & 338 & 8.2 & 4.2 & 3.4 & 38 & 79.5 \\
\hline CTCS & 6.6 & 19.2 & 304 & 9.3 & 6.1 & 1.9 & 47 & 89.5 \\
\hline MTCS & 5.3 & 8.2 & 36 & 4.6 & 4.1 & 7.2 & 34 & 55.9 \\
\hline NTCS & 5.3 & 8.0 & 63 & 4.9 & 3.1 & 6.0 & 39 & 58.6 \\
\hline
\end{tabular}

SB: sum of bases

detergent solution and taking off after three days in the field (BARETTA et al., 2003). After removal, the organisms in the traps were collected, sifted, sorted, counted, identified and preserved in $80 \%(\mathrm{v} / \mathrm{v})$ ethyl alcohol solution.

The data of organisms abundance in the traps of each LUS were used to calculate Shannon diversity index (H), Simpson dominance index (Is), Pielou equitability index (e) and taxa richness (total number of taxa) (ODUM, 1983). The Shannon diversity index was obtained by the formula $\mathrm{H}=-\sum$ pi. $\log$ pi, where: $\mathrm{pi}=\mathrm{ni} / \mathrm{N}, \mathrm{ni}=$ density of each group, family or species when identified, $\mathrm{N}=$ total number of groups (family or species when identified). Other ecological parameters (Is, $e$ and group richness) were calculated as described in Baretta et al. (2003).

\section{Statistical analysis}

Microbiological attributes $\left(\mathrm{MBC}\right.$ and $\left.\mathrm{CO}_{2}-\mathrm{C}\right)$ were subjected to analysis of variance (ANOVA) and means were compared by LSD test $(P<0.05)$, using the SAS software version 9.2 (SAS INSTITUTE, 2008).

The abundance of each taxonomic group of soil fauna in different LUS was used to obtain the length of the gradient (DCA), however, because this length was less than three, it was decided to apply a principal component analysis (PCA) using the program CANOCO version 4.0 (TER BRAAK; SMILAUER, 1998). The chemical (pH, OM, P, K, Ca, Mg, H + Al), physical (resistance to penetration and soil moisture), microbial soil attributes ( $\mathrm{MBC}$ and $\mathrm{CO}_{2}-\mathrm{C}$ ) and chlorophyll content were used later in the PCA, as explanatory environmental variables of the changes of the fauna attributes (TER BRAAK; SMILAUER, 1998).

In addition, all environmental variables (soil physical, chemical and microbiological attributes) and the main soil fauna data were submitted to canonical discriminant analysis (CDA) to identify the most important ones for the separation of LUS (BARETTA et al., 2006) discussing in acordance to their indicator value, as recommended by Baretta et al. (2010).

\section{RESULTS AND DISCUSSION}

\section{Microbial Biomass Carbon (MBC)}

The values of Microbial Biomass Carbon (MBC) and basal respiration $\left(\mathrm{C}-\mathrm{CO}_{2}\right)$ were influenced $(P<0,05)$ by soil management system (Figures $1 \mathrm{~A}$ and $1 \mathrm{~B}$ ) and were discussed apart because of its importance for the evaluation of soil quality (PEREIRA et al., 2013). As there was no effect of the seasons, the data were discussed independent of the season for $\mathrm{MBC}$ and $\mathrm{CO}_{2}-\mathrm{C}$.

The LUS no-tillage with crop rotation (NTCR) and minimum tillage with crop succession (MTCS) showed higher MBC compared to no-tillage with crop succession (NTCS) and conventional tillage with crop rotation (CTCR), followed by conventional tillage with crop succession (CTCS), where LUS NTCS did not differ significantly from CTCS not (Figure 1A).

In general, management systems with less soil disturbance such as no-tillage (NTCR) and minimum tillage (MTCS), presented better soil conditions and permanence of the cover on the soil surface. These advantages were attributed to the longer time of adoption of these systems, consequently raising the MBC values (BALOTA et al., 2004). Thus, the amount and composition of $\mathrm{MBC}$ are influenced by several factors, including the tillage system and the crop rotation. The increased activity of microorganisms observed may be associated with crop rotation in the NTCR, since the diversification of the remaining soil material constitutes a factor for the effectiveness of the microorganisms activity (FONSECA et al., 2007; PEREIRA et al., 2013; VENZKE-FILHO et al., 2008).

For soil microbial activity $\left(\mathrm{CO}_{2}-\mathrm{C}\right)$, the LUS notillage and conventional tillage with crop rotation (NTCR and CTCR) and the conventional tillage with crops succession (CTCS) showed the highest values of $\mathrm{CO}_{2}$ $\mathrm{C}$ compared to no-tillage (NTCS) and minimum tillage (MTCS) with crop succession (Figure 1B). These high values in conventional systems may be associated with 
excessive soil tillage and management. High levels of $\mathrm{CO}_{2}-$ $\mathrm{C}$ released, also indicate large number of microorganisms. The opposite is also true, however, these high values of respiration are not always good indicators because that may mean high microbial activity and rapid release of plant nutrients which in a long term, may reflect in losses of the total organic carbon. Thus, the soil microbial activity is used as an additional assessment to MBC (HUNGRIA et al., 2009; PEREIRA et al., 2013).

Now, for NTCS and MTCS sites, the release of $\mathrm{CO}_{2}-\mathrm{C}$ was lower, due to minimal soil disturbance, with smaller and slower losses of carbon (Figure 1B).

Figure 1 - Microbial biomass carbon $\left[\mathrm{MBC}\left(\mathrm{mg} \mathrm{C} \mathrm{g}^{-1}\right)\right]$ (A) and microbial basal respiration $\left[\left(\mathrm{CO}_{2}-\mathrm{C}, \mathrm{mg} \mathrm{g}^{-1}\right.\right.$ dry soil)] (B) in different land use systems (CTCR: Conventional plantation with crop rotation; NTCR: No-tillage with crop rotation; CTCS: conventional tillage with crop succession; NTCS: no-tillage with crop succession; MTCS: Minimum tillage with crop succession), independent of the season (winter and summer). Means with same low case letter do not differ by LSD test $(P<0.05)$; $T$ Standard deviation)
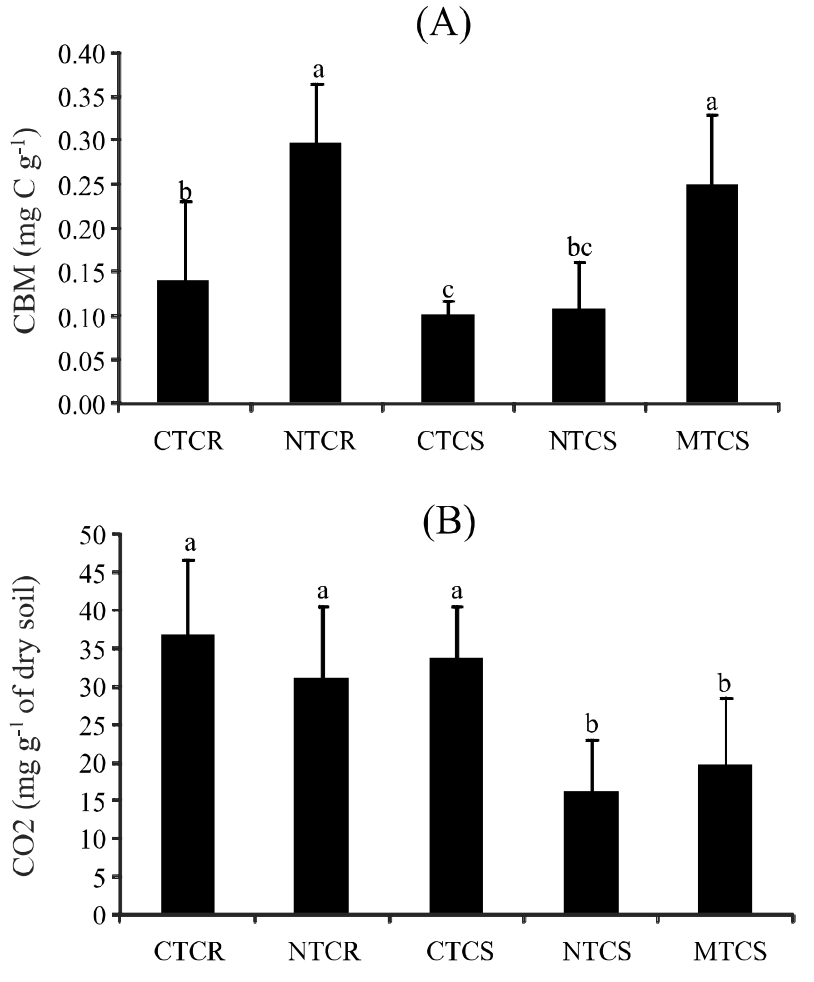

Principal component analysis (PCA) for soil fauna and explanatory environmental variables

The first principal component (PC1) explained $35.5 \%$ and the second (PC2) $22.7 \%$ totalizing $58.2 \%$ of the data variability. Throughout the PC1 (Axis 1), in the right lower side, the groups Coleoptera, Isopoda and group richness were strongly associated with notillage (NTCR) and conventional tillage with crop rotation (CTCR), showing a similarity between these management systems. The highest diversity, dominance and equitability indexes [Shannon $(\mathrm{H})$, Simpson (Is) Pielou $(e)]$, respectively, were also more associated with NTCR and CTCS sites, being explained by the better soil chemical conditions, especially potassium $(\mathrm{K})$, calcium $(\mathrm{Ca})$ and organic matter $(\mathrm{OM})$, among others such as $\mathrm{pH}, \mathrm{Mg}$ and soil moisture (Figure 2). NTCR site also presented a higher amount of OM in the surface layers and greater moisture condition of the soil, promoting the formation of a suitable environment for a greater quantity and diversity of edaphic groups, especially Coleoptera, Isopoda and Others. Crop rotation promoted diversification of the plants residue content and quality of this remaining material. This combination of factors contributes to the understanding of a higher occurrence of taxa in this management system, validating results obtained in soils of Santa Catarina by other authors (ALVES et al., 2006; BARETTA et al., 2003; BARETTA et al., 2006).

As reported by several authors, the conserved management systems associated to crop rotation contribute to the optimal development of soil fauna, besides the high relationship with soil fertility due to increased biological activity (ALVES et al., 2008; BARETTA et al., 2003; FONSECA et al., 2007; SILVA et al., 2006; SILVA et al., 2013). In contrast, the no-till with crop succession (NTCS) showed a lower occurrence and diversity of soil organisms and larger amounts of potential acidity $(\mathrm{H}+\mathrm{Al})$, higher than the optimal values (Figure 2). Therefore the crop succession should not be recommended when the objective is to benefit and to preserve soil biodiversity, regardless of the type of soil tillage and management.

The high content of $\mathrm{H}+\mathrm{Al}$ in the crop succession sites (NTCS and MTCS) may be associated with failures in the implementation of the system and/ or even failures in the management. In this case, the lack of crop rotation and the absence of correction of the soil fertility, which may subsequently weaken the balance of the system may have caused losses in productivity and sustainability, particularly in terms of the soil fauna diversity.

In the present study, the groups Collembola, Araneae, Hymenoptera, Orthoptera, Grylloblattodea, Lepidoptera and the total abundance of soil fauna were not associated to any particular LUS. However, the PCA is not as recommended as the CDA to select indicators of sustainability and soil quality (BARETTA et al., 2010). 
Figure 2 - Relation between Principal Component 1 (PC1) and 2 (CP2) of the Principal Component Analysis (PCA) for the abundance of the soil fauna groups (in italics) and physical, chemical and microbiological attributes (red arrows) (RP020: penetration resistance in the $0-20 \mathrm{~cm}$; $\mathrm{pH}$ : Potential hydrogenionic in water; OM: organic matter; P: phosphorus; K: potassium; Ca: calcium, $\mathrm{Mg}$ : magnesium; $\mathrm{H}$ + Al: potential acidity and Moisture: soil moisture; CBM: microbial biomass carbon, $\mathrm{C}-\mathrm{CO} 2$ : basal respiration ) in the different LUS (gray arrows) (CTCR: conventional plantation with crop rotation; NTCR: no-tillage with crop rotation; CTCS: conventional tillage with crop succession; NTCS: notillage with crop succession; MTCS: minimum tillage with crop succession). ( $\mathrm{n}=5$ LUS $\times 9$ sampling points $\mathrm{x} 3$ true replicates $\mathrm{x}$ mean of the 2 seasons $=145$ )

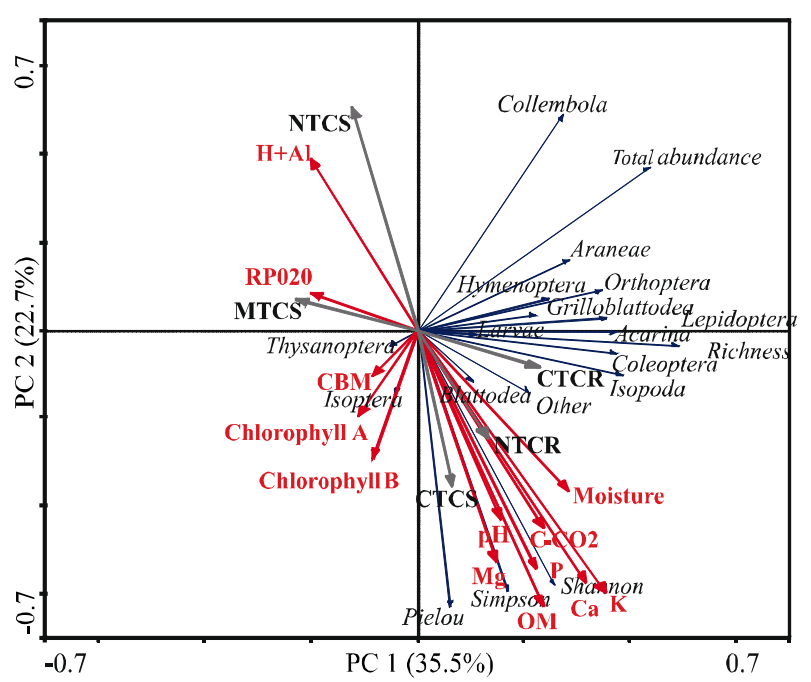

The resistance to penetration in the depth of 0 $20 \mathrm{~cm}$ (RP020) on the other hand, was more associated with the MTCS due to the use of heavy equipment in the planting process of crops in recent years (Table 2). Furthermore, during the winter, the sites were exposed to an excessive intake of grazing animals (cattle) and stocking up was recommended for the region, which contributed to a higher soil compaction.

\section{Canonical discriminant analysis (CDA)}

The CDA was performed because it is more recommended for discriminating LUS and to know which were the environmental variables that contributed better to separate them (BARETTA et al., 2006).

The statistical test (Wilks' Lambda) indicated significant differences $(P<0.0001)$ between the management systems as the soil fauna attributes and the explanatory environmental variables, presented as the canonical discriminant function $1\left(\mathrm{FCD}_{1}\right)$ and $2\left(\mathrm{FCD}_{2}\right)$
(Table 4 and Figure 3). The attributes that present division relation and there who are strongly correlated were removed from the $\mathrm{CDA}$, increasing the reliability of this analysis, and reducing the effect of data colinearity (BARETTA et al., 2010).

The $\mathrm{FCD}_{1}$ and $\mathrm{FCD}_{2}$ showed $70.4 \%$ and $21.4 \%$ of canonical correlations, respectively (Figure 3 ). These two functions were adjusted to explain the variations found in the values of environmental and soil fauna variables, and to help evidencing that the CDA is more recommended than the PCA, especially when CDA is significant.

Figure 3 shows the canonical standardized coefficients (CCP) of FCD 1 and $\mathrm{FCD}_{2}$ for the five LUS, considering all environmental and soil fauna variables studied. The CCP explains the multivariate behavior of the different soil attributes analyzed to promote the separation between the LUS, in response to the study of the independent variables simultaneously analyzed (BARETTA et al., 2006). Thus, it is possible to observe that FCD $_{1}$ separated the LUS CTCS, with higher values of the standardized coefficients (CCP), of the NTCR and CTCR sites. The CTCS site was disposed in the upper right quadrant, apart from the other LUS. Since the MTCS and NTCS sites were arranged in the left quadrant there are not differences among themselves (Figure 3).

Figure 3 - Relation between the first and second canonical discriminant function $\left(\mathrm{FCD}_{1}\right.$ and $\left.\mathrm{FCD}_{2}\right)$ on the mean (centroid, in black) of the standardized canonical coefficients (CCP), for the studied environmental variables, discriminating CTCR: conventional plantation with crop rotation; NTCR: no-tillage with crop rotation; CTCS: conventional tillage with crop succession; NTCS: no-tillage with crop succession and MTCS: minimum tillage with crop succession, independent of the season. ( $n=5$ LUS x 9 sampling points $\times 3$ true replicates $\times 2$ seasons $=270$ )

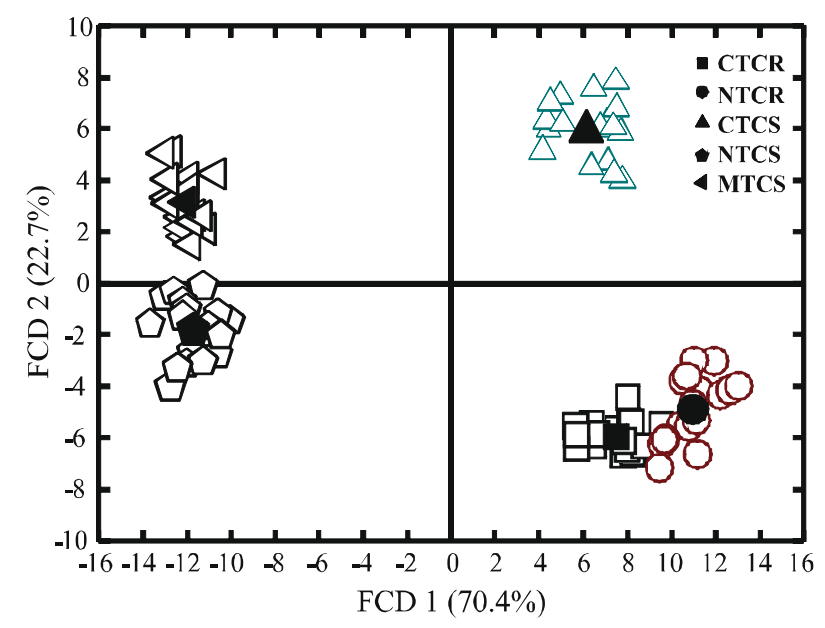


Table 4 - Canonical correlation coefficient $(r)$, standardized canonical coefficient (CCP) and Parallel Discriminating Rate Coefficient (PDRC) as the canonical discriminant functions 1 and 2 (FCD1 and FCD2), regarding the environmental and soil fauna variables, independent of land use system and seasons

\begin{tabular}{|c|c|c|c|c|c|c|}
\hline \multirow{2}{*}{ Variables } & \multicolumn{3}{|c|}{$\mathrm{FCD}_{1}(70.4 \%)$} & \multicolumn{3}{|c|}{$\mathrm{FCD}_{2}(21.4 \%)$} \\
\hline & $r$ & $\mathrm{CCP}$ & PDRC & $r$ & $\mathrm{CCP}$ & PDRC \\
\hline \multicolumn{7}{|c|}{ Frequently soil fauna groups and attributes } \\
\hline Isoptera & 0.01 & -0.14 & 0.00 & -0.02 & -0.09 & 0.00 \\
\hline Coleoptera & 0.00 & 0.03 & 0.00 & 0.00 & -0.12 & 0.00 \\
\hline Acarina & 0.02 & 0.09 & 0.00 & 0.04 & -0.10 & 0.00 \\
\hline Thysanoptera & -0.01 & 0.08 & 0.00 & 0.01 & -0.08 & 0.00 \\
\hline Diptera & 0.00 & -0.18 & 0.00 & 0.01 & -0.01 & 0.00 \\
\hline Lepidoptera & 0.03 & 0.43 & 0.00 & -0.06 & 0.05 & 0.00 \\
\hline Larvea & 0.01 & -0.14 & 0.00 & -0.02 & -0.03 & 0.00 \\
\hline Araneae & 0.00 & -0.31 & 0.00 & -0.03 & -0.19 & 0.01 \\
\hline Grilloblattodea & 0.00 & 0.07 & 0.00 & -0.01 & 0.01 & 0.00 \\
\hline Collembola & -0.03 & -0.26 & 0.03 & -0.07 & -0.08 & 0.01 \\
\hline Orthoptera & -0.01 & -0.17 & 0.00 & -0.02 & -0.04 & 0.00 \\
\hline Isopoda & 0.05 & 0.12 & 0.01 & -0.04 & 0.04 & 0.00 \\
\hline Hymenoptera & 0.02 & 0.00 & 0.00 & 0.03 & 0.25 & 0.01 \\
\hline Blattodea & 0.01 & 0.12 & 0.00 & 0.02 & 0.04 & 0.00 \\
\hline Others $^{(1)}$ & 0.00 & 0.12 & 0.00 & 0.00 & 0.14 & 0.00 \\
\hline Abundance & 0.01 & 0.00 & 0.00 & -0.03 & 0.00 & 0.00 \\
\hline Taxonomic group richness & 0.02 & 0.34 & 0.01 & 0.00 & 0.16 & 0.00 \\
\hline Shannon diversity index $(\mathrm{H})$ & 0.06 & 0.37 & 0.04 & 0.04 & 0.43 & 0.02 \\
\hline Simpson dominance index (Is) & 0.06 & -1.01 & -0.03 & 0.05 & -0.25 & -0.01 \\
\hline Pielou equitability index (e) & 0.05 & 0.61 & 0.03 & 0.05 & 0.02 & 0.00 \\
\hline \multicolumn{7}{|c|}{ Environment variables } \\
\hline Chlorophyll A content & -0.04 & 0.00 & 0.00 & 0.47 & 0.24 & 0.11 \\
\hline Chlorophyll B content & -0.01 & 0.08 & 0.00 & 0.46 & 0.29 & 0.13 \\
\hline \multicolumn{7}{|c|}{ Soil microbiological attributes } \\
\hline Microbial biomass carbon (MBC) & -0.04 & -0.07 & 0.02 & 0.07 & 0.08 & 0.01 \\
\hline Basal respiration $\left(\mathrm{CO}_{2}-\mathrm{C}\right)$ & 0.12 & 0.13 & 0.00 & -0.08 & -0.09 & 0.01 \\
\hline \multicolumn{7}{|c|}{ Physical and chemical attributes ${ }^{(2)}$} \\
\hline $\mathrm{pH}$ & 0.14 & -1.62 & -0.22 & 0.25 & 2.28 & 0.57 \\
\hline Calcium $(\mathrm{Ca})$ & 0.29 & 1.43 & 0.41 & 0.21 & -1.12 & -0.23 \\
\hline Magnesium (Mg) & 0.04 & -1.20 & -0.05 & 0.13 & 1.78 & 0.22 \\
\hline Phosphorus (P) & 0.18 & 0.35 & 0.06 & 0.14 & -0.08 & -0.01 \\
\hline Potassium (K) & 0.63 & 1.12 & 0.65 & 0.18 & -0.05 & -0.01 \\
\hline Organic matter (OM) & 0.24 & -0.12 & -0.03 & 0.37 & 0.69 & 0.25 \\
\hline Potential acidity $(\mathrm{H}+\mathrm{Al})$ & -0.13 & -0.37 & 0.05 & -0.09 & 1.05 & -0.09 \\
\hline Penetration resistence (RP: 0-20 cm) & -0.03 & -0.04 & 0.00 & 0.01 & 0.34 & 0.00 \\
\hline Soil moisture & 0.16 & 0.10 & 0.02 & -0.05 & -0.21 & 0.01 \\
\hline
\end{tabular}

(1) Other: sum of the soil organisms less frequent; ${ }^{(2)}$ Soil attributes measured only in the first season (summer) 
In general, it was possible to observe that the $\mathrm{FCD}_{1}$ separated crop rotation sites, NTCR and CTCR, with higher values of the canonical standardized coefficients (CCP) compared to the other sites with crop succession CTCS, MTCS and NTCS, respectively (Figure 3).

\section{Parallel Discriminating Rate Coefficient (PDRC)}

The PDRC value shown in Table 4 is the result of the product of the CCP and the correlation $(r)$. The $r$ shows univariate information (individual contribution) of each edaphic attribute studied, independent of the others. Therefore, the best parameter for evaluating the effect of separation generated by the attributes within the soil management systems is the PDRC (BARETTA et al., 2006).

The use of $P D R C$ gives an indicator value for the studied attributes. From these results of $P D R C$ of the CDA analysis Baretta et al. (2010) proposed the separation of the soil quality indicators in six classes based on the indicator value obtained. This separation is useful in the choice of soil attributes that are most sensitive to promote differences among management systems (Table 4).

And finally, it is possible to note that within the $\mathrm{FCD}_{1}$, the group Collembola (0.03), Shannon diversity index (0.04), Pielou equitability index (0.03), soil moisture (0.02), microbial biomass carbon (0.02), calcium (0.41), phosphorus (0.06), potassium (0.65) and potential acidity (0.05) exhibited the highest positive values of PDRC coefficient, indicating that the major effect of separation of the LUS is explained by these variables (Table 3). In $\mathrm{FCD}_{2}$, the environmental variables with the highest PDRC were: the Shannon diversity index (0.02), the chlorophyll A content (0.11) and B (0.13), pH (0.57), magnesium (0.22) and organic matter (0.25). According Baretta et al. (2010), the indicator value is: $\leq 0.03$ (low), 0.04 to 0.09 (medium), 0.10 to 0.20 (good), 0.21 to 0.41 (very good), from 0.42 to 0.80 (optimum) and $>0.81$ (excellent).

\section{CONCLUSIONS}

1. The soil fauna has the potential to be used in the evaluation of soil quality because some groups were sensitive to changes in environmental variables, to the soil tillage and management, therefore it may help in the monitoring of an ecological management with higher biodiversity;

2. The soil management systems with crop rotation (NTCR and CTCR) presented the highest soil diversity, compared to the management systems with crop succession (CTCS, MTCS and NTCS), demonstrating the beneficial effect of crop rotation for conservation of soil biodiversity, independent of sampling time (winter and summer);

3. The "best" indicators to separate the land use systems are: potassium, $\mathrm{pH}$, calcium, organic matter, phosphorus, potential acidity, Shannon diversity index, Collembola, Pielou equitability index, microbial biomass carbon, respectively;

4. New studies are suggested involving the evaluation of the soil macrofauna using other sampling methods, such as soil monoliths, since the traps assess only the activity of the soil fauna living on the surface of the soil, limiting the sampling of other groups of organisms, such as earthworms.

\section{ACKNOWLEDGMENT}

The authors thank Agrisus Foundation for financial support and Dr. Ondino Battaglia for the suggestions in the project. As well, thank the CETREC/ EPAGRI for allowing the use of the experimental sites and help and the farmers who allowed the study in their farms in the counties Chapecó, Xanxerê and Ouro Verde. The authors thank the Department of Animal Science, the official Gilberto François and UDESC/ CEO for the support. We acknowledge Dra. Cintia Carla Niva (Universidade Positivo/UP, Curitiba-PR) and anonymous referees for their critical and helpful comments.

\section{REFERENCES}

ALEF, K.; NANNIPIERI, P. (Ed.) Methods in applied soil microbiology and biochemistry. London: Academic Press, $1995.576 \mathrm{p}$.

ALVES, M. V.; BARETTA, D.; CARDOSO, E. J. B. N. Fauna edáfica em diferentes sistemas de cultivo no estado de São Paulo. Revista de Ciências Agroveterinárias, v. 5, n. 1, p. 33-43, 2006.

ALVES, V. et al. Macrofauna do solo influenciada pelo uso de fertilizantes químicos e dejetos de suínos no Oeste do Estado de Santa Catarina. Revista Brasileira de Ciência do Solo, v. 32, n. 2, p. 589-598, 2008.

BALOTA, E. L. et al. Long-term tillage and crop rotation effects on microbial biomass and $\mathrm{C}$ and $\mathrm{N}$ mineralization in a Brazilian Oxisol. Soil \& Tillage Research, v. 77, n. 2, p. 137-145, 2004.

BARETTA, D.; BROWN, G.G.; CARDOSO, E.J.B.N. Potencial da macrofauna e outras variáveis edáficas como indicadores da qualidade do solo em áreas com Araucaria angustifolia. Acta Zoológica Mexicana (nueva serie), v. 26, n. 2, p. 135-150, 2010. 
BARETTA, D. et al. Análise multivariada da fauna edáfica em diferentes sistemas de preparo e cultivo do solo. Pesquisa Agropecuária Brasileira, v. 41, n. 11, p. 1675-1679, 2006.

BARETTA, D. et al. Fauna edáfica avaliada por armadilhas de catação manual afetada pelo manejo do solo na região oeste catarinense. Revista de Ciência Agroveterinárias, v. 2, p. 97-106, 2003.

BARTZ, M. L. C.; PASINI, A.; BROWN, G. G. Earthworms as soil quality indicators in Brazilian No-tillage systems. Applied Soil Ecology, v. 69, n. 7, 39-48, 2013.

BARTZ, M. L. C. et al. Earthworm richness in land-use systems in Santa Catarina, Brazil. Applied Soil Ecology, 2014. http://dx.doi.org/10.1016/j.apsoil.2014.03.003.

BROOKES, P.C. The use of microbial parameters in monitoring soil pollution by heavy metals. Biology Fertily of Soils, v.19, n. 4, p.269-279, 1995.

DUPONT, T. et al. No-tillage conversion of harvested perennial grassland to annual cropland reduces root biomass, decreases active carbon stocks, and impacts soil biota. Agriculture, Ecosystems \& Environment, v. 137, n. 1-2, p. 25-32, 2010.

FEBRAPDP (Federação Brasileira de Plantio Direto e Irrigação). Metodologia de Qualificação do Plantio Direto, 2013. Available in: [http://plantio. hidroinformatica.org/images/pdf/Metodologia_de Qualifica\%C3\%A7\%C3\%A3o_do_Plantio_Direto.pdf ]. Last access: 24/09/2013.

FONSECA, G. C. et al. Atributos físicos, químicos e biológicos de Latossolo de Cerrado sob duas rotações de cultura. Pesquisa Agropecuária Tropical, v. 37, n. 1, p. 2230, 2007.

HUNGRIA, M. et al. Soil microbial activity and crop sustainability in a long-term experiment with three soiltillage and two crop-rotation systems. Applied Soil Ecology, v. 42, n. 3, p. 288-296, 2009.

LAVELLE, P. et al. Soil invertebrates and ecosystem services. European Journal on Soil Biology, v. 42, Supplement 1, p. S3S15, 2006.

LIMA, A. C. R. et al. A functional evaluation of three indicator sets for assessing soil quality. Applied Soil Ecology, v. 64, n. 2, p. 194-200, 2013.
ODUM, E. P. Ecologia. Rio de Janeiro: Guanabara. 1983. 434 p.

PAOLETTI, M. G.; BRESSAN, M. Soil invertebrates as biodicators of human disturbance. Critical Reviews in Plant Sciences, v. 15, n. 1, p. 21-62, 1996.

PEREIRA, J. DE. M. et al. Relationships between microbial activity and soil physical and chemical properties in native and reforested Araucaria angustifolia forests in the state of São Paulo, Brazil. Revista Brasileira de Ciência do Solo, v. 37, n. 3, p. 572-586, 2013.

SAS INSTITUTE. SAS/STAT: Qualification Tools user's guide, version 9.2 Cary, 2008.

SILVA, V. R.; REINERT, D. J.; REICHERT. J. M. Densidade do solo, atributos químicos e sistema radicular do milho afetados pelo pastejo e manejo do solo. Revista Brasileira de Ciência do Solo, 24: n.1, 191-199, 2000.

SILVA, R. F.; AQUINO, A. M.; MERCANTE, F. M.; GUIMARÃES; M. F. Macrofauna invertebrada do solo sob diferentes sistemas de produção em latossolo da região do Cerrado.Pesquisa Agropecuária Brasileira, v. 41, n. 4, p. 697704, 2006.

SILVA, R. F. et al. Fauna edáfica influenciada pelo uso de culturas e consórcios de cobertura do solo. Pesquisa Agropecuária Tropical, v. 43, n. 2, 2013.

TEDESCO, M. J. et al. Análises de solo, plantas e outros materiais. Porto Alegre, Universidade Federal do Rio Grande do Sul, 1995. 174 p, (Boletim Técnico 5).

TER BRAAK, C. J. F.; SMILAUER, P. CANOCO reference manual and user's guide to Canoco for Windows: software for canonical community ordination (version 4). New York: Microcomputer Power, 1998.

USDA - Soil Survey Staff. Soil Taxononmy - a basic system of soil classification for making and interpreting soil survey. 2 ed., Washington: USDA. 1999. 871 p.

VANCE, E. D.; BROOKS, P. C.; JENKINSON, D. S. An extraction method for measuring soil microbial biomass C. Soil Biology and Biochemystry, v. 19, n. 6, p. 703-707, 1987.

VENZKE-FILHO, S. P. V.; FEIGL, B. J.; PICCOLO, M. C. Biomassa microbiana do solo em sistemas de plantio direto na região de Campos Gerais - Tibagi, PR. Revista Brasileira de Ciência do Solo, v. 32, n. 2, p. 599-610, 2008. 